\title{
METODY KREOWANIA TYMCZASOWYCH PRZESTRZENI PUBLICZNYCH
}

\author{
Natalia Przesmycka \\ Katedra Architektury, Urbanistyki I Planowania Przestrzennego, Wydział \\ Budownictwa i Architektury, Politechnika Lubelska \\ e-mail: n.przesmycka@pollub.pl
}

\begin{abstract}
Streszczenie. Tymczasowe zagospodarowanie lub wykreowanie przestrzeni publicznych staje się coraz bardziej powszechnym zjawiskiem, występującym zwłaszcza w dużych miastach. Jest to zjawisko pozostające niejako poza głównym nurtem zainteresowaniem badaczy urbanistyki współczesnych miast, jednak będące jednym z podstawowych elementów polityki miejskiej. Tymczasowe zagospodarowanie przestrzeni publicznych może mieć różne przyczyny: brak środków na docelowe zagospodarowanie, chęć spróbowania czy dany rodzaj funkcji sprawdzi się w wybranej lokalizacji, czy oddolne nie zawsze legalne działanie społeczne, wynikające z bieżących potrzeb mieszkańców lub użytkowników. Niektóre przestrzenie publiczne zagospodarowane tymczasowo pozostają w swojej formie i funkcji na dłużej, inne są demontowane lub po prostu się zużywają. W niniejszym artykule przedstawiono wybrane przykłady tymczasowych przestrzeni publicznych z europejskich miast.
\end{abstract}

Słowa kluczowe: temporary public spaces, urban reuse, urban art

\section{WPROWADZENIE}

W tradycyjnej, ukształtowanej w drodze historycznego rozwoju formie miasta o europejskich korzeniach, najważniejszą przestrzenią publiczną jest rynek lub plac oraz ulice. Tradycyjnie rozumiana przestrzeń publiczna charakteryzowała się pewną stałością: jej obszar wyznaczały budynki lub inne materialne ściany, zaś elementy wyposażenia były rozmieszczone w sposób trwały, wyznaczając ramy dla wybranych aktywności jej użytkowników. Przestrzenie publiczne drugiej dekady XXI wieku odzwierciedlają zmieniający się styl życia mieszkańców i użytkowników miast. W krajach bardziej rozwiniętych już w latach 70-tych zaczęto wprowadzać ograniczenie transportu samochodowego (Dania, Holandia). Obecnie transformacje przestrzeni publicznych zmierzają w kierunku uczynienia ich bardziej „ludzkimi”, wielofunkcyjnymi i elastycznie reagującymi na zmieniające się potrzeby społeczeństwa. Paradoksalnie, istniejące w krajach rozwijających ulice i place, na których rozgrywa się życie codzienne, się są celem do którego dążą kraje rozwinięte. Współczesne miasto zamieszkiwane przez wiele grup etnicznych, narodowościowych i wyznaniowych nie może być tak spójne jak miasta historyczne. Jest nadmiernie fragmentaryczne, pełne kontrastów i tarć, a zatem musi mieć wiele twarzy - jedna nie wystarczy. Jego otwartość sprawia, że jest tak atrakcyjne dla rosnącej rzeszy jego mieszkańców. Brak spójnego i wyrazistego obrazu miasta może być więc zaletą, a nie wadą czy problemem.l Tymczasowe przestrzenie publiczne są nieodłącznym elementem współczesnego miasta. Elastyczne, wielofunkcyjne lub czasowe wykorzystanie przestrzeni może być kreowane na wiele sposobów.

Codzienna struktura życia miasta generuje stałe, zmienne i ulotne sposoby funkcjonowania przestrzeni publicznych ${ }^{2}$. Tradycyjne place rynkowe były przestrzeniami wielofunkcyjnymi. Ich podstawową funkcją było miejsce spotkań, wymiany informacji, handlu i usług.

1 Rykwerth J., 2013, Pokusa miejsca. Przeszłość i przyszłość miast. Międzynarodowe Centrum Kultury, Kraków, s. 25

2 Jan Gehl, Miasto dla ludzi, Kraków, RAM 2014, p. 145. Autor wielokrotnie podkreśla znaczenie kreowania tych zdarzeń dla udanej polityki miejskiej. 
W zależności od rangi miasta centralny plac stawał się okresowo miejscem zgromadzeń z okazji różnych wydarzeń: publicznych egzekucji, jarmarków, świąt religijnych itd. Czasami wydarzenia te odbywały się poza wyznaczonymi ramami, np. pod bramą miejską lub na przedpolach miasta. Wówczas przestrzeń ta stawała się tymczasową przestrzenią publiczną. W okresie renesansu starano się wykreować przestrzenie publiczne o bardziej określonych funkcjach i charakterze. Wielofunkcyjne rynki ustąpiły miejsca placom o zdefiniowanych funkcjach. Określenie funkcji polegało nie tylko na prawnym ujęciu ale przede wszystkim na wyposażaniu przestrzeni w stałe elementy wyposażania np. baseny wodne do prania bielizny, baseny do pojenia zwierząt i osobne studnie do czerpania wody pitnej, arkadowe wolnostojące zadaszenia lub arkady obramowujące plac. Pośrednio inspirowane regularnymi założeniami antycznych forów cesarskich zaczęły powstawać place powiązane ważnymi budynkami użyteczności publicznej (władz miasta, rządu lub rezydencji mieszkalnej). Od XVI wieku nieodłącznym elementem reprezentacyjnej przestrzeni publicznej był konny pomnik władcy lub wodza. Dopiero w XIX i XX wieku w większości dużych miast pojawiły się przestrzenie otwartych placów, projektowanych najczęściej jako miejsce - arena dla wielkich zdarzeń publicznych. Te reprezentacyjne miejsca funkcjonowały (i wiele z nich nadal tak funkcjonuje) przy ważnych budynkach państwowych, podczas obchodów świąt czy narodowych uroczystościach. Pozbawione innych funkcji, wykorzystywane są przez mieszkańców jako przestrzeń komunikacji, zaś turystów przyciągają do nich atrakcje w sąsiadujących gmachach. Obecnie odpowiednie funkcjonowanie takich przestrzeni zapewnia ich animowanie poprzez tymczasowe wydarzenia kulturalne, sportowe, społeczne czy artystyczne. Zawsze dobrze sprawdza się wprowadzenie elementu handlu, targowiska ulicznego. Sięganie do tradycji jarmarków stało się elementem polityki promocyjnej wielu polskich miast np. Lublin - Jarmark Jagielloński, Jarmark Dominikański w Gdańsku itd. Wydarzenia te ożywiają przechodnie przestrzenie i oferują możliwość uczestnictwa w życiu miejskim wielu grup społecznych i wiekowych.

Tymczasowe wykorzystanie przestrzeni publicznych spełnia również ważną rolę w polityce miejskiej. Miastem, którego władze dostrzegły, jak ważne może być tymczasowe nadanie funkcji publicznej przestrzeniom będącym w trakcie transformacji był Berlin. W czasie, gdy stolica połączonych Niemiec przechodziła wielką przebudowę, wiele przestrzeni pozostawało pustych. Tymczasowe wykorzystanie ich do celów publicznych stało się elementem strategii transformacji, poddając je jednocześnie próbie (w aspekcie społecznym i ekonomicznym) celowości zagospodarowania w kierunku wybranej funkcji. Czasowe użytkowanie odbywało się równolegle z procesem planowania przestrzennego, a projekty tymczasowego wykorzystania przestrzeni zostały włączone w strategię transformacji, która jest nadal kontynuowana. ${ }^{3}$

\section{MOBILNE ELEMENTY W PRZESTRZENIACH PUBLICZNYCH}

Najbardziej popularnym mobilnym elementem w przestrzeni publicznej, kreującym jej tymczasowe wykorzystanie, jest krzesło. Stałe miejsca do siedzenia w przestrzeni publicznej wiązały się z jej architekturą. W renesansie powszechne było projektowanie kamiennych ław, wkomponowanych w cokoły budynków, na których można było usiąść. Przenośne meble miejskie wywodzą się idei przestawnych, drewnianych ławek ogrodowych, typowych dla założeń parkowych w stylu angielskim. Jako meble miejskie pojawiły się parkach Nowego Jorku (Bryant Park) i Paryża, w II połowie XX wieku. Idea ta bardzo szybko rozprzestrzeniła się w większych miastach bardziej rozwiniętych krajów. Obecnie najbardziej popularne są miejskie leżaki, okresowo wykładane w różnych przestrzeniach miejskich (Ryc. 1. B). Składane meble miejskie mają wiele zalet: są łatwe w przechowywaniu, a puste pozostawione na

3 Urban Pioneers, Berlin: stadtenentwicklung durch Zwischennutzung, Senatverwaltung fur Stadtenwicklung Berlin und Jovis verlag GmbH, Berlin 2007 
placach czy w parkach w zimne miesiące przywołują wspomnienia nadmorskiego kurortu poza sezonem. ${ }^{4}$

Elementy mobilne nie muszą być niewielki i lekkie. Od 2002 roku w Wiedniu wykorzystuje się wielkoskalowe mobilne meble miejskie. Wieloboczne kształty umożliwiają zestawianie mebli w nieskończoną ilość form, każdego roku zaskakując kolorami i rozmieszczeniem. Tak zwane ENZI nie są klasycznymi ławkami. Zaprojektowane przez PPAG Architects dla dziedzińców Dzielnicy Muzeów stały się rozpoznawalnym elementem przestrzeni miejskiej (Ryc. 1. A). Wielofunkcyjna modularność i żywa, zmieniająca się corocznie kolorystyka mebli, stała się jednym $\mathrm{z}$ elementów tożsamości centrum miasta. Na zimę meble są składowane $\mathrm{w}$ strukturach przypominające budowle, wewnątrz których mogą odbywać się koncerty lub pokazy kinowe. Wykonane z odpornego na czynniki atmosferyczne tworzywa meble weszły również do sprzedaży detalicznej.
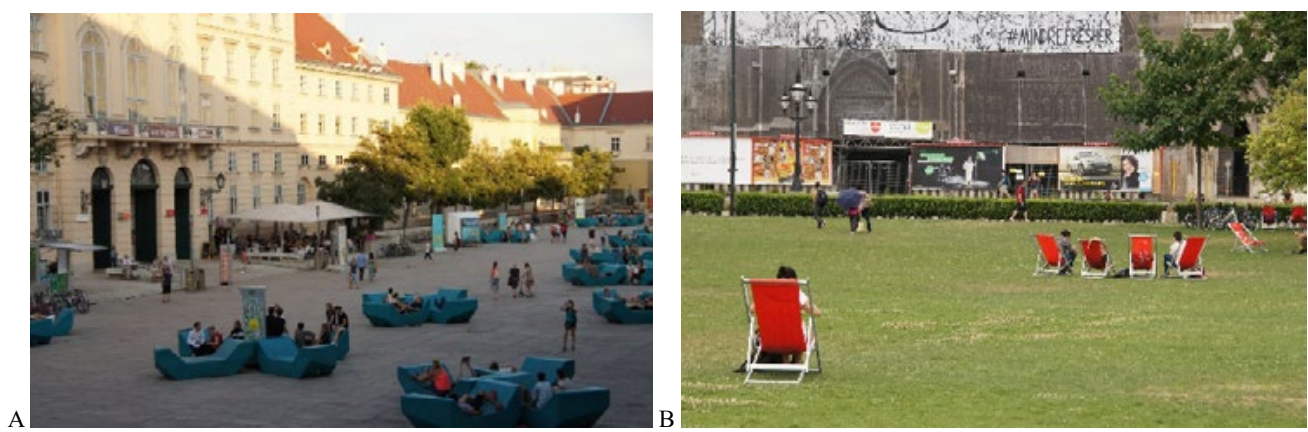

Ryc. 1. A - Enzi, wielofunkcyjne meble miejskie w Wiedniu, B - leżaki miejskie przed Votivkirche, Wiedeń Fot. N. Przesmycka

Fig. 1. A - Enzi, multifunctional street furniture in Vienna, B - folded chairs at Votivkirche in Vienna. Photo N. Przesmycka

Podobna idea - wielofunkcyjnego mebla miejskiego zastosowana została w projekcie grupy Studio Weave zatytułowanym 140 Boomerangs. ${ }^{5}$ Modularne elementy w kształcie bumerangów wykonanych z wodoodpornej sklejki w naturalnym kolorze drewna pojawiły się w kilku miejscach przestrzeni publicznej Londynu z okazji Biennale Architektury. Bumerangi ustawiane w różnych konfiguracjach i łączone ze sobą pod różnym kątem tworzyły siedziska, stoły, fotele lub instalacje rzeźbiarskie. Naturalny materiał dobrze wpisywał się w różne przestrzenie" pasując zarówno do zabytkowego parku w West Smithfield, gdzie rzeźbiarska forma na kształt wstęgo opasywała fontannę, jak i do wnętrza ulic. Studio Weave Architects specjalizują się z działań na pograniczu sztuki i architektury poprzez wprowadzanie do przestrzeni publicznej tymczasowych instalacji i interakcji w swoich działaniach z lokalną społecznością. Projekt tymczasowego pawilonu The Smith w Clerkenwell został w 2015 roku wybrany w konkursie Civic Trust Award zwycięzcą kategorii tymczasowych instalacji wpływających pozytywnie na sferę publiczną. ${ }^{6}$

Od kreatywnego podejścia do kształtowania tymczasowych elementów w przestrzeni publicznej zależy nie tylko jej jakość estetyczna, ale również emocjonalny stosunek do niej użytkownika - poczucie bezpieczeństwa lub zagrożenia, czy chęć zatrzymania się. Elementem niezbędnym podczas wykonywania prac budowlanych są ogrodzenia placu budowy. Są one wykorzystywane do wielu celów, najczęściej jako nośniki reklam. W miejscach historycznych

4 Jan Gehl, Miasto..., op. cit., p. 145.

5 Ch. Van Uffelen, 2010; Street Furniture, s. 66-69, Braun.

$6 \mathrm{http}: / /$ studioweave.com/ 
powszechnie przyjętą praktyką jest odtwarzanie na ogrodzeniach lub osłonach rusztowań zakrytych elewacji. Lepszemu funkcjonowaniu przestrzeni, której użytkowanie jest ograniczone w wyniku budowy może sprzyjać połączenie ogrodzenia z funkcją informacyjną (Ryc. 2.). Podane w komunikatywny, atrakcyjny wizualnie sposób informacje o tym co dzieje się za ogrodzeniem, nie wyłącza przestrzeni $\mathrm{z}$ funkcjonowania miasta.
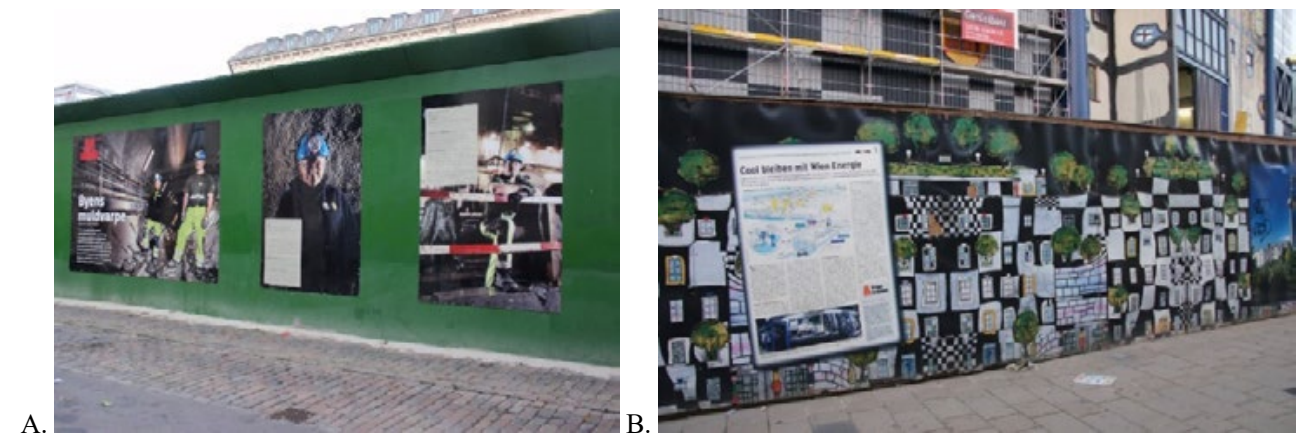

Ryc. 2. Różna rola ogrodzeń w przestrzeni publicznej. A- informacja i edukacja (Kopenhaga, budowa metra), B - informacja i podniesienie estetyki przestrzeni (Wiedeń, ogrodzenie placu budowy przy spalarni odpadów zaprojektowanej przez Hunderwassera). Fot. N. Przesmycka

Fig. 2. Different role of fences in public space. A- information and education (Copenhagen, the construction of the subway), B - information and improving of appearance of public space (Vienna, the fence at the building site of the waste incineration plant designed by Hunderwasser). Photo. N. Przesmycka

\section{ROZWIĄZANIA NISKOBUDŻETOWE I ARTYSTYCZNE - RECYKLING W ARANŻACJI PRZESTRZENI TYMCZASOWYCH}

Indywidualnie zaprojektowane meble miejskie i elementy małej architektury stwarzają poczucie unikalności miejsca i mogą być elementem chroniącym miasto przed unifikacją i anonimowością. Jednym z ulubionych przez architektów, artystów i dizajnerów materiałem używanym obecnie do realizacji tymczasowego zagospodarowania przestrzeni publicznej są europalety. Palety mają wiele zalet: zunifikowane rozmiary, stabilną konstrukcję, są tanie i łatwo dostępne. Sięgają po nie zarówno znane biura architektoniczne, jak i sami mieszkańcy lub użytkownicy terenu, chcący poprawić jego funkcjonalność. Estetycznym przykładem aranżacji przestrzeni tymczasowej jest realizacja z 2014 roku przy Copenhagen Business School (Ryc. 3. A.). W sąsiedztwie uczelni wykonano z palet rodzaj amfiteatru i wielopoziomowych siedzisk, kreując wielofunkcyjna przestrzeń, która w zamierzeniu miała służyć nie tylko studentom, ale i okolicznym mieszkańcom. W użyciu europalet w działaniach artystycznych specjalizuje się holenderska pracownia REFUNC. W lipcu 2012 roku na warszawskim Targówku z ponad 200 europalet powstała zgodnie z projektem pracowni wielofunkcyjna przestrzeń rekreacyjna dla użytkowników w każdym wieku . Była to kontynuacja pierwszej w Polsce instalacji artystycznej wykonanej całkowicie z materiałów wtórnych. Przy skrzyżowaniu ulic św. Wincentego i Kondratowicza, na tyłach dzielnicowego ratusza, zbudowano m.in. domek z palet i siedziska ze starych opon. ${ }^{8}$ Projekt wzbudził kontrowersje - mieszkańcy nie do końca przekonali się do idei recyklingu. Wielu instalacja kojarzyła się ze śmietniskiem, a poniesione łączne koszty w wysokości 80 tys. złotych wydały się wygórowane. Być może w polskim społeczeństwie idea recyklingu zbyt mocno kojarzy się z ,aranżacjami” przestrzeni

7 http://refunc.nl/?cat=216

8 http://www.targowek.info/2012/07/pomnik-palety-robi-sie-wiekszy/ 
z lat minionych (np. placów zabaw czy boisk sportowych), kiedy powszechnie w użyciu były stare opony, występujące w roli ogrodzeń lub donic.

A.
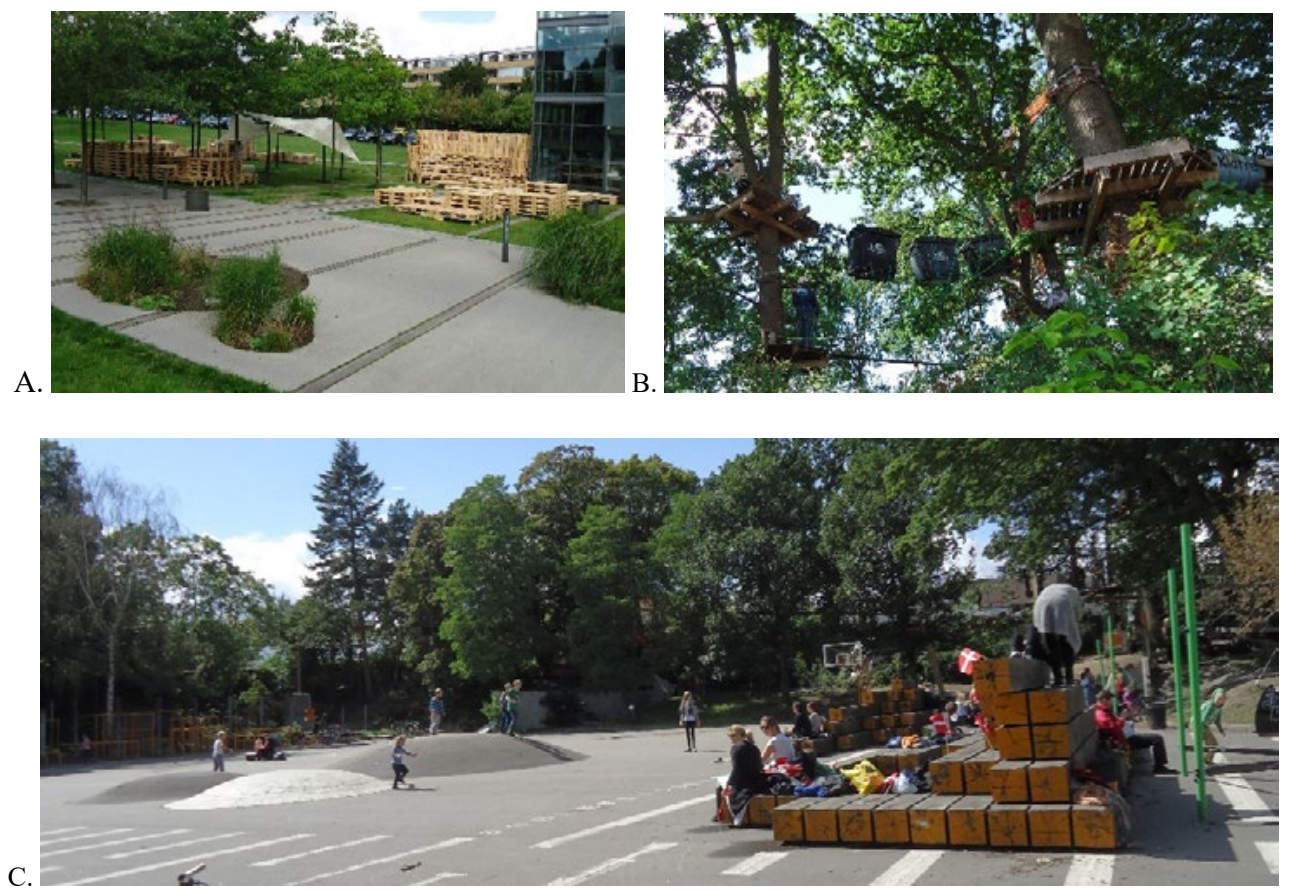

Ryc. 3. A - Aranżacja wielofunkcyjnej przestrzeni tymczasowej z palet. Kopenhaga. B - Fot. N. Przesmycka

Fig. 3. The temporary arrangement of the multifunctional space made from wooden pallets. Photo N. Przesmycka

Inaczej na aranżowanie przestrzeni publicznych elementami z pochodzącymi recyklingu patrzy się w wysokorozwiniętych krajach. Ponownie można odwołać się do przykładu pochodzącego z Kopenhagi, miasta, które w wielu niezależnych rankingach zawsze znajduje się w czołówce najlepszych przestrzeni publicznych i miejsc do zamieszkania. Kopenhaga jest miastem, w którym do jakości przestrzeni publicznych i ich odpowiedniego funkcjonowania przykłada się ogromną wagę. Po przeniesieniu produkcji piwa Carlsberg z browaru w dzielnicy Vesterbro do miejscowości Fredericia w 2006 roku, podjęto próby rewitalizacji terenu poprzemysłowego i „dowartościowania” tym samym dzielnicy mieszkaniowej. W procesie rewitalizacji zorganizowano kilka interesujących przestrzeni publicznych, które w zamierzeniu wykonane jako tymczasowe, odgrywają zasadniczą rolę w zapewnieniu integracji planowania, budowy i rozwoju życia miejskiego, w okresie przejściowym. Jako pierwszą przestrzeń zaaranżowano plac Tap E Plads. (Ryc. 3. C). Jego najważniejszym elementem jest wykonany z podkładów kolejowych wielofunkcyjny mebel miejski. Mebel ma formę amfiteatralnego wygodnego siedziska, skierowanego w stronę zorganizowanych w sąsiedztwie placów dedykowanych różnym rodzajom zabaw i aktywności fizycznej.

W obrębie placu wykorzystując przedmioty z recyklingu stworzono tymczasowy park linowy (Ryc. 3. B). Podwieszone do drzew beczki, zbiorniki, kontenery na śmieci, palety a nawet samochód, tworzą przygodową przestrzeń zabaw dla osób w różnym wieku. Przylegające przestrzenie powstały w bardzo prosty sposób: oznaczenia malowane na asfalcie dzielą plac na strefy; biała ściana szczytowa sąsiadującego budynku może być wykorzystywana do projekcji filmowych, meczów piłki nożnej i innych działań twórczych. Kolejna tymczasowa przestrzeń 
w bezpośrednim sąsiedztwie to Boble Plads. ${ }^{9}$ Jest to miejsce aktywnego wypoczynku, dedykowane miłośnikom parkuru, deskorolkowcom i rowerzystom (BMX). Wielofunkcyjność tworzą asfaltowe wybrzuszenia, uliczny kosz do koszykówki.

Tymczasowe przestrzenie publiczne o różnym charakterze przyciągają $\mathrm{w}$ rejon dawnej fabryki mieszkańców i turystów, a teren ten na dobre zaistniał w zbiorowej świadomości jako miejsce przyjazne kulturze, sztuce, alternatywnym wydarzeniom i swobodnemu spędzaniu czasu na wolnym powietrzu. ${ }^{10}$

Oddolne działania mieszkańców widoczne są w drobnej skali: organizowania miejskich ogródków warzywno - kwiatowych i przestrzeni sąsiedzkich (przykład kopenhaskiej dzielnicy Byhaven). Do kreacji przestrzeni mieszkańcy chętnie używają pochodzących z recyklingu przedmiotów i materiałów budowlanych, osiągając estetyczny efekt. ${ }^{11}$. Własnymi siłami budują domy dla owadów, miejsca do siedzenia i spożywania posiłków, grille, kuchnie i piece. Podobne inicjatywy obywatelskie stały się popularne w ostatnich kilkunastu latach, obejmując swoim zasięgiem większość miast w krajach bardziej rozwiniętych.

Innym ciekawym przykładem recyklingu w przestrzeni miejskiej jest plac zabaw zrealizowany w portowej części Reykiaviku. Plac zrealizowano w części miasta, która od 1995 roku jest konsekwentnie rewitalizowana. Część likwidowanego dawnego portu remontowego jest likwidowana, a dla uatrakcyjnienia tej części miasta wprowadzane są nowe obiekty usługowe. Plac zabaw ma charakter tymczasowy, wpisując się pomiędzy teren budowy a nadbrzeże. Na placu zabaw znalazły się stare elementy związane z żeglugą: części statków, liny okrętowe, szpule, opony, sieci itd. Tworzą one atrakcyjne dla dzieci i młodzieży struktury do wspinaczki i kreatywnej zabawy ${ }^{12}$. Inny, nieszablonowy plac zabaw w Rejkiawiku znajduje się w miejskim lesie, w sąsiedztwie Keiluhöllin. Jego realizacja jest przykładem działania niskobudżetowego, lecz bardzo pomysłowego. Dookoła leśnej polany wybrano kilka drzew, którym przycięto odpowiednio gałęzie, tak by w naturalny sposób zachęcały do wspinania po nich. Kilka kładek i równoważni zbudowanych z drewna dopełnia całości, a tablice informacyjne objaśniają $\mathrm{w}$ jakim zakresie można korzystać $\mathrm{z}$ tego naturalnego placu zabaw.

A.

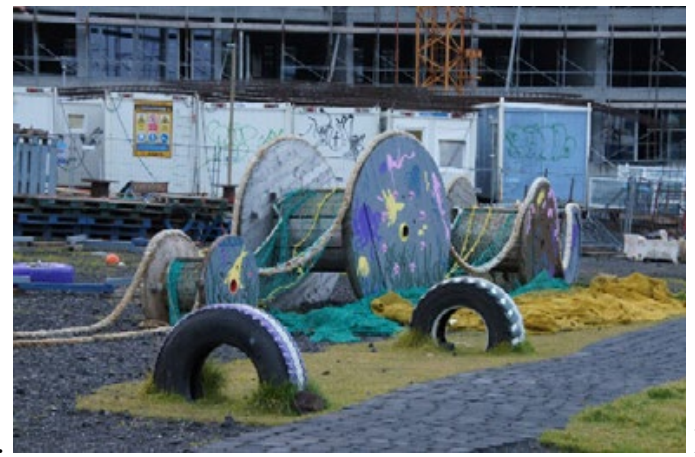

Ryc. 4. Niskobudżetowe place zabaw w Rejkiawiku. A - przy starym porcie, B - w lesie. Fot. N. Przesmycka Fig. 4. Low-cost playgrounds in Reykjavík. A - in the old port area, B - in a forrest. Photo. N. Przesmycka

9 Boble Plads zawdzięcza swoją nazwę sąsiedniemu obiektowi, Boblehallen, z charakterystycznym dachem w kształcie bańki. Kiedy pogoda się pogarsza, sporty uliczne mogą znaleźć swoje miejsce w pomieszczeniach Boblehallen.

$10 \mathrm{http} / /$ www.dac.dk/en/dac-life/copenhagen-x-gallery/cases/temporary-urban-spaces-at-carlsberg/

$11 \mathrm{http}: / /$ byhaven2200.dk/

12 Podobnym przykładem jest zrealizowany w 2008 roku Geopark w Stavanger (Norwegia). Jest to założenie rekreacyjne skierowane do wszystkich grup użytkowników (plac zabaw, skate park, przestrzeń wystawiennicza,) Do stworzenie aranżacji użyto wielu elementów po przemyśle ropy naftowej. 
Ponowne użycie elementów budowlanych lub przemysłowych wzbogaca przestrzeń publiczną nadając jej indywidualny charakter. Tak prosty element jak pachołek uliczny może być wykonany $\mathrm{z}$ dowolnego trwałego materiału lub elementu. $\mathrm{W}$ miastach skandynawskich często $\mathrm{w}$ ich roli występują naturalne głazy narzutowe lub tylko z grubsza ociosane kamienne elementy. We włoskim mieście Ravello użyto do tego celu fragmentów antycznych kolumn, co jest zgodne z lokalną tradycją. Ale używane są również mniej szlachetne materiały z nie mniej dobrym skutkiem. W 2006 roku we francuskiej miejscowości Le Havre przed ratuszem stanęła wykonana na z 90.000 plastikowych kul (bombek świątecznych) instalacja na pergoli ${ }^{13}$. Różowe, błękitne i pomarańczowe kule tworząc zwisające grona pięknie komponują się z naturalną zielenią pergoli. Zadaszenie chroni przed światłem i deszczem, a delikatnie poruszając się na wietrze wprowadza dodatkowy element wzbogacający krajobraz akustyczny miejsca.

Niskobudżetowa aranżacja przestrzeni publicznej jest zgodna z ideą rozwoju zrównoważonego. Oszczędność środków finansowych najczęściej wiąże się z nieszablonym myśleniem i wykorzystaniem potencjału prostych rozwiązań.

\section{DZIAŁANIA ARTYSTYCZNE I NOWA ROLA SZTUKI W KREOWANIU PRZESTRZENI}

Sztuka w przestrzeni publicznej była obecna od początków istnienia miast. W swoim oficjalnym nurcie przez stulecia ograniczyła się do przyozdobienia miejsca lub zaistnienia jako pomnik lub rzeźba. Pomniki, ołtarze czy inne elementy rzeźbiarskie nadawały jej rangi reprezentacyjnej. W ostatnich latach zmienia się rola i miejsce sztuki. U progu XXI wieku zyskała nowy wymiar. Często sztuka sygnalizuje publiczny wymiar przestrzeni.

W przestrzeniach publicznych większości miast obecny jest street $\operatorname{art}^{14}$. Ten rodzaj sztuki, w swoim założeniu działającej intensywnie i okresowo, jest świadomie wykorzystywany przez władze miejskie, w procesach rewitalizacyjnych i do promocji miast. Zaakceptowanie murala władze miasta i mieszkańców jest warunkiem jego zaistnienia podczas festiwali street artu. Jest to niejako sprzeczne z ideą nurtu street artu, u którego podstawy leży niepodleganie żadnym wpływom i tworzenie komunikatów dla wszystkich odbiorców. ${ }^{15}$

13 Ch. van Uffelen, Street..., op. cit., s. 422-425

14 Określenia street art najprawdopodobniej po raz pierwszy użył Allan Schwartzman w 1985, za: T. Sikorski: Czy street art jest sztuka? W: E. Dymna, M. Rutkiewicz: Polskie street art, cz.2. Między anarchia, a galeria. s.373. Carta Blanca. Jednym z prokursorów street artu jest Banksy, artysta który używa różnych technik do przekazywania swoich wiadomości, najczęściej humorystycznych lub związanych z polityką. Jego technika łącząca ze sobą graffiti i technikę szablonową oraz odważne umiejscowienie prac, zyskały uznanie krytyków i została zauważone przez media.

15 Sebastian Frąckiewicz, Żeby było ładnie. Rozmowy o boomie i kryzysie street artu w Polsce, Poznań 2015. 

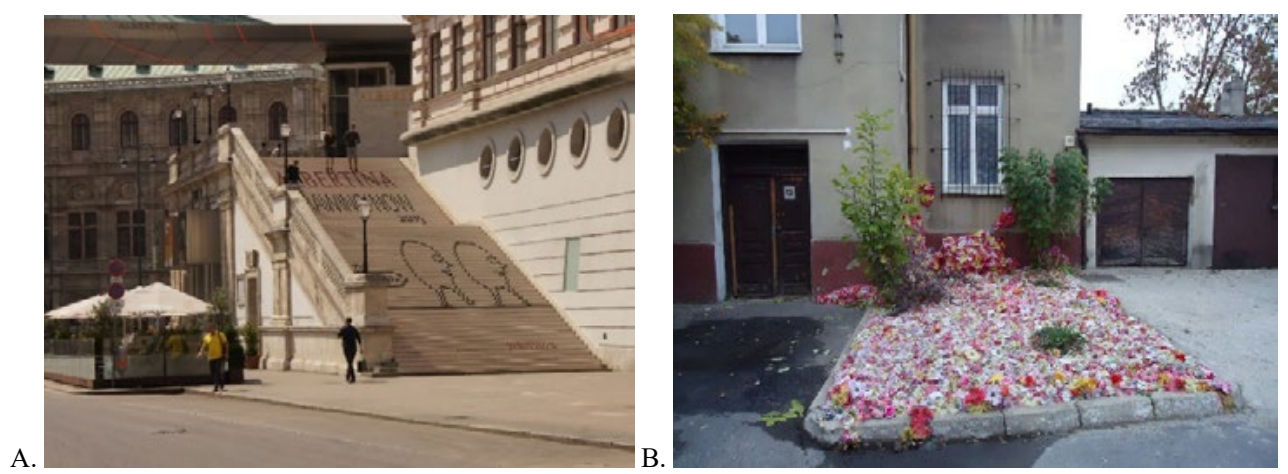

Ryc. 5. A - Wiedeń, schody do muzeum Albertiny (2015), B - instalacja artystyczna na Podwórku Sztuki w Lublinie przy ul. Narutowicza (2013), Fot. N. Przesmycka

Fig. 5. A - Vienna, the stairs to the Albertina Museum (2015), B - art installation in the Courtyard of Art in Lublin, Narutowicza Street (2013). Photo. N. Przesmycka.

Działania artystyczne w przestrzeni publicznej mogą mieć różną formę: od kameralnych, często anonimowych inicjatyw po międzynarodowe festiwale, mające nadać miastu odpowiednią rangę. Wiele wydarzeń ma charakter cykliczny, a różne rodzaje sztuk łączą się ze sobą. Obecnie sztuka miejska, zwłaszcza w formie murali, jest elementem polityki promocyjnej miasta, po który władze chętnie sięgają. Festiwale street artu są popularnym zjawiskiem w dużych miastach. ${ }^{16}$ Jednym z najsłynniejszych przykładów jest miasto Melburne, gdzie wspólna przestrzeń miasta stała się galerią sztuki współczesnej. Oprócz stałej ekspozycji obecne są liczne wystawy i instalacje czasowe, a duże znaczenie mają działania interaktywne z widzami. Przykładem jak silnie może oddziaływać na strefę społeczną sztuka w przestrzeni miejskiej jest instalacja autorstwa Julity Wójcik - Tęcza na Placu Zbawiciela w Warszawie. Ten tymczasowy (istniejący od 2011 do 2015 roku) element artystyczny wywoływał skrajne emocje. W 2013 roku w trakcie trwania demonstracji narodowych tęcza została podpalona. ${ }^{17}$

Przykładem, jak obecność sztuki może łagodzić nastroje społeczne i sprzyjać integracji jest instalacja Chiński Smok na placu Martina Moniza w Lizbonie. Plac ten stał się w ostatnich latach centrum szybko rozwijającej się dzielnicy chińskiej. Rzeźba zbudowana jest z elementów z recyklingu: opon, metalu, części podzespołów elektronicznych. Długa na kilkanaście metrów wyłania się i chowa pod powierzchnia placu. Jest jego centralnym elementem i mimo, że nie dominuje gabarytami, od niedawna plac nazywany jest Placem Smoka. Na co dzień plac jest miejscem wielofunkcyjnym i wielonarodowościowym - przestrzenią spotkań emigrantów z Chin i innych krajów. Znajdujący się na środku smok z okazji świąt jest malowany lub przystrajany, stając się ważnym elementem wydarzeń, na co dzień stanowi świetny plac zabaw dla dzieci, które wspinają się na rzeźbę, zjeżdżają z niej i biegają dookoła. Historia rewitalizacji tej przestrzeni jest długa. Do placu przylegają najbardziej zdegradowane dzielnice śródmiejskie, a sąsiadujące $\mathrm{z}$ nim centra komercyjne i biznesowe nie mają żadnego powiązania

16 Specyficzny rodzaj street artu pojawił się na wsiach, tzw. rurales w Polsce uprawia artysta Daniel Rycharski. za http://wydzialsztuki.up.krakow.pl/?page_id=2809

17 Artystka znana jest również z innych zaangażowanych akcji w przestrzeniach społecznych i miejskich. Jedna z pierwszych była „Rewitalizacja Parku Schopenhauera” w cieszącej się złą sławą dzielnicy Gdańska - Oruni (2002), gdzie na pewien czas sprowadziła trzy kozy z zoo w Oliwie. Wyjadając chwasty, strzygąc trawę i stanowiąc atrakcję dla dzieci miały one za zadanie przywrócić porządek w tym zapomnianym przez lokalnych włodarzy zakątku. Z kolei na Gradowej Górze w Gdańsku artystka postawiła błękitną piaskownicę pomalowaną w białe obłoczki jako akcent kontrastujący ze znajdującym się tam ogromnym stalowym krzyżem („Piaskownica z widokiem", 2002). za: http://culture.pl/pl/tworca/julita-wojcik. Piaskownica po dwóch tygodniach została skradziona 
z przestrzenia placu. ${ }^{18}$ Pod placem zbudowano wielkoprzestrzenny parking, a przestrzeń szybko stała się miejscem spotkań narkomanów, dilerów narkotyków i prostytutek. Pierwszą próbę rewitalizacji placu podjęto w 1997 roku poprzez ustawienie na nim 40 kiosków ${ }^{19}$. Niestety próba zamienienia placu $\mathrm{w}$ przestrzeń handlową, oferująca regionalne produkty i pamiątki nie sprawdziła się. W 2000 roku większość z kiosków usunięto i plac na powrót stał się jedną otwartą przestrzenią, której sposób funkcjonowania definiowany jest przez użytkowników. Projekt aranżacji przestrzeni publicznej nie sprawdził się: sztuczna trawa, zadaszenia i pawilony kawiarniane nie funkcjonują zgodnie z założeniem władz miasta i architekta, a plac nadal odbierany jest jako miejsce dosyć niebezpieczne i generujące społeczne patologie. Plany rewitalizacji zakładające współistnienie wielokulturowych stref (bary i kawiarnie serwujące kuchnie z różnych stron świata) nie do końca się sprawdziły. W obrębie placu nadal funkcjonuje świat przestępczy. Rzeźba smoka jest jedynym elementem, który spaja przestrzeń, nadaje jej charakteru i integruje użytkowników.
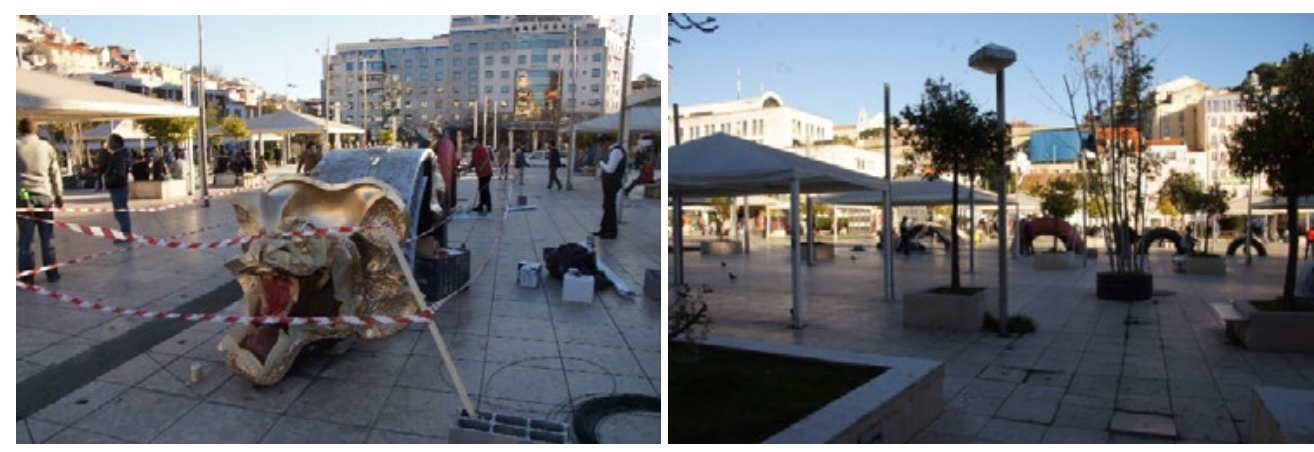

Ryc. 6. Plac Martina Moniza w Lizbonie, rzeźba smoka w trakcie przemalowywania na złoto. Fot. N. Przesmycka.

Fig. 6. Martin Moniz Square in Lisbon, the sculpture of dragon undergoing a repainting process. Photo. N. Przesmycka.

Tymczasowe zagospodarowanie przestrzeni publicznych może posłużyć do zwiększenia bezpieczeństwa oraz włączenia miejsc jeszcze nie oddanych do użytkowania w system przestrzeni publicznych. Obszary zabudowy wymagające największych interwencji nie muszą być całkowicie wyłączone ze struktury przestrzeni publicznych miasta. Wykonywane na czas trwania prac budowlanych, lub wyłączenia obiektów, tymczasowe aranżacje przestrzeni, oparte $\mathrm{w}$ dużej mierze na działaniach artystycznych. Widocznym elementem zwiększającym atrakcyjność takich obszarów są murale, które pokrywają ślepe ściany noszące ślady wyburzeń oraz ogrodzenia placów budowy. W ten sposób przestrzeń śródmiejska nie traci na swojej atrakcyjności, nawet w czasie budowy.

18 Plac powstał w latach 40. XX wieku w ramach akcji porządkowania miasta I organizacji nowych przestrzeni.

19 Rita Aguiar Rodrigues, A Warning to Lisbon: The Fight for Meaning in Martim Moniz, http://www.failedarchitecture.com/a-warning-to-lisbon-the-fight-for-meaning-in-martim-moniz/ 

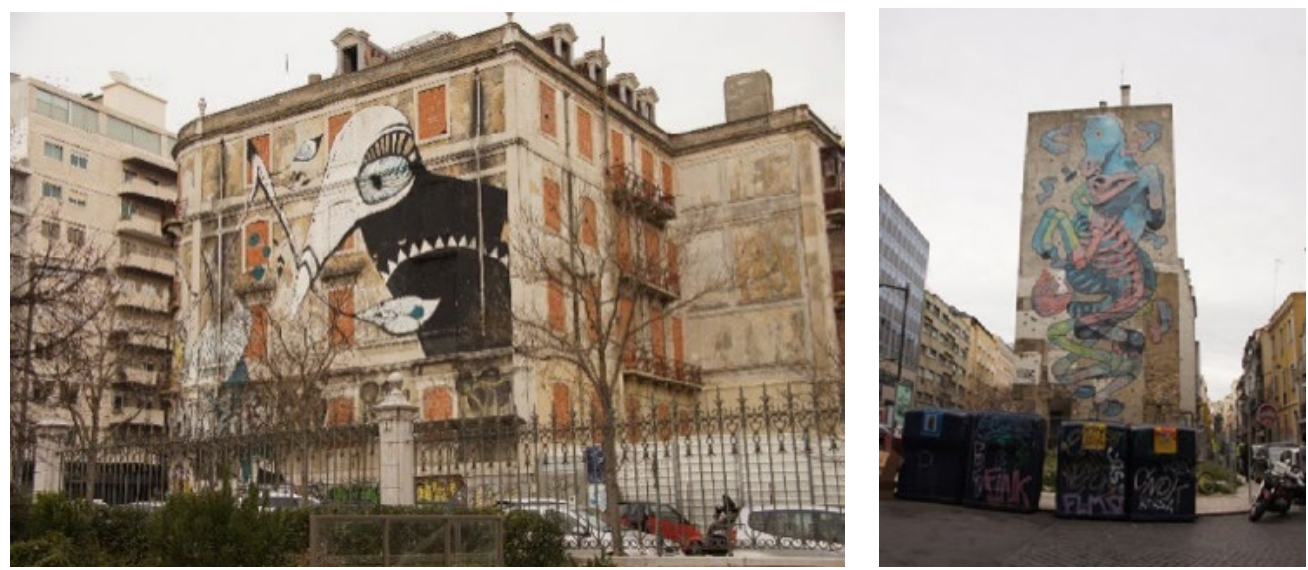

Ryc. 7. Przykłady murali jako sztuki poprawiającej wygląd elewacji obiektów przeznaczonych do remontu lub rozbiórki, Lizbona, Fot. N. Przesmycka.

Fig. 7. Examples of mural art improving the aesthetics of the buildings' elevations which are dedicated to be demolished or renewed, Photo. N. Przesmycka

W kreowaniu przestrzeni publicznych ważna role odgrywają również elementy rzeźbiarskie, które często przyjmują niespotykane formy. Rzeźba może być dowcipna, lekka, i tymczasowa. Może nawet oderwać się od ziemi i zamiast tradycyjnie na cokole, być zainstalowana pod niebem (Ryc. 8). Ten sposób wprowadzenia elementu rzeźbiarskiego do przestrzeni publicznej definiuje ją w nowy sposób: oprócz ścian i podłogi we wnętrzu urbanistycznym zaczyna być dostrzegane „sklepienie”. Wiszące rzeźby podnoszą atrakcyjność przestrzeni nie ograniczając jej użytkowania. Rzeźbiarze szczególnie często posługują się w swoich działaniach motywem postaci ludzkiej.

Ciekawym przykładem działania rzeźbą w kreowaniu atrakcyjnych przestrzeni publicznych jest dzielnica Aker Brygge w Oslo. Tereny dawnego portu remontowego zostały poddane procesowi rewitalizacji i przebudowy, tworząc w tym miejscu nowoczesną, modną dzielnicę śródmiejską. Funkcje mieszkaniowe, usługowe, handlowe przenikają się, a całość „spina” atrakcyjna przestrzeń publiczna. Istotną rolę odgrywa w niej rzeźba - zarówno ta zainstalowana na stałe, jak i instalacje tymczasowe. W letnie, ciepłe dnie dzielnicę odwiedza 35.000 osób z całego miasta. Dzielnica została zaprojektowana z myślą o wysokiej jakości przestrzeni publicznej i ,aktywnych" parterach oferujących usługi, które w przyszłości przyciągną określonych użytkowników ${ }^{20}$.

Rzeźba współczesna w odróżnieniu od klasycznej, tworzona jest często z myślą o jej aktywnym odbiorze. Istniejąc $\mathrm{w}$ przestrzeni publicznej jest nie tylko obiektem do oglądania, ale zachęca do podejścia bliżej, dotknięcia, usiądnięcia na niej czy przy niej, a przede wszystkim do sfotografowania. Można stwierdzić, że atrakcyjna rzeźba kreuje tymczasowe użytkowanie przestrzeni publicznej poprzez zamierzoną interakcję z odbiorcą (Ryc. 8. D, E, 9).

20 Nie znajdziemy tu salonu sprzedaży Mercedesa ani McDonalda, ale raczej mniejsze i średnie firmy, oraz wysokiej jakości mieszkania. Moor M., Rowland J., (red.) Urban Design Futures, Tylor\&Francis Group 2006. 


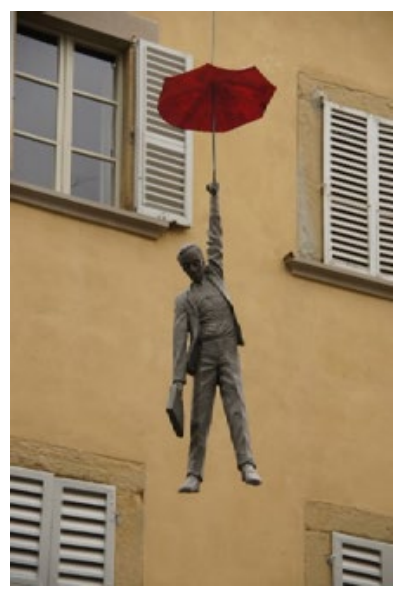

A

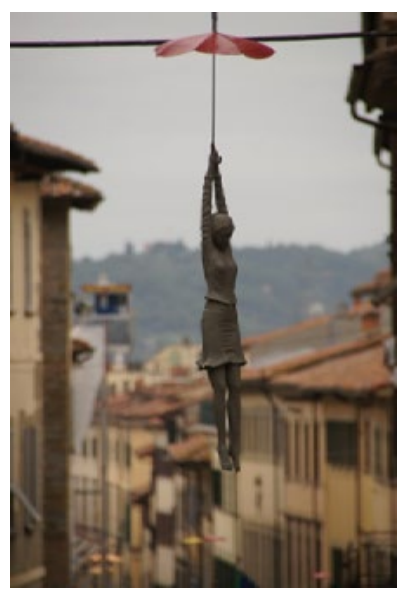

B

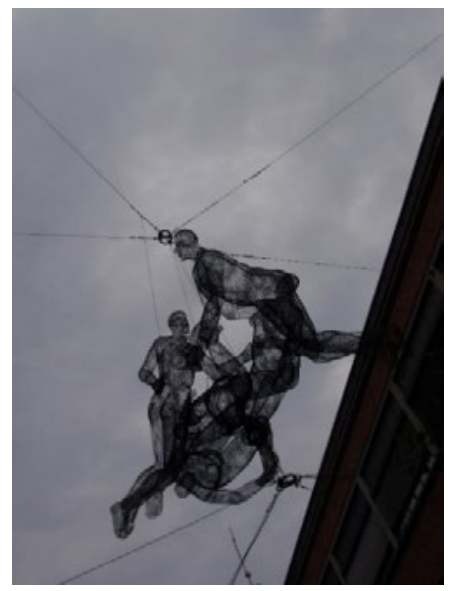

$\mathrm{C}$
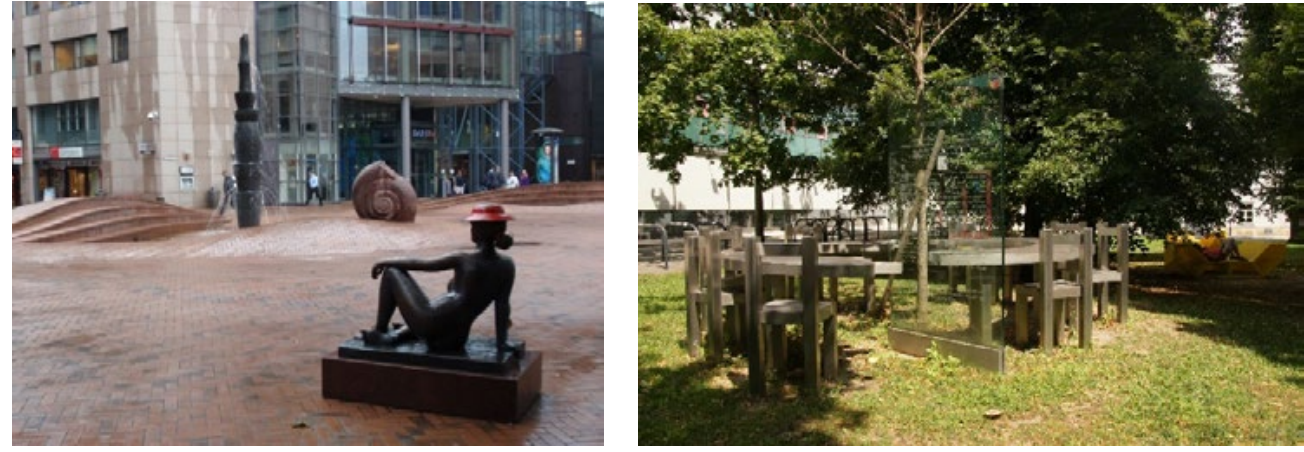

E

Ryc. 8. Instalacja artystyczna Lekka niepewność, autorstwa czeskiego rzeźbiarza Michała Trapaka Arezzo, Włochy. C, D - Aker Brygge, Oslo - instalacja i rzeźby zintegrowane z przestrznią publiczną - Aker Brygge, Oslo, E - Wiedeń, dziedziniec uniwersytetu - Fot. N. Przesmycka Fig. 8. An artistic instalation: Light uncertainty by Michał Trapak, Czech sculptor, in Arezzo, Italy, C - Aker Brygge, Oslo - outdoor art installation and sculptures integrated into public space , E -the courtyard of the University of Vienna. Photo N. Przesmycka 


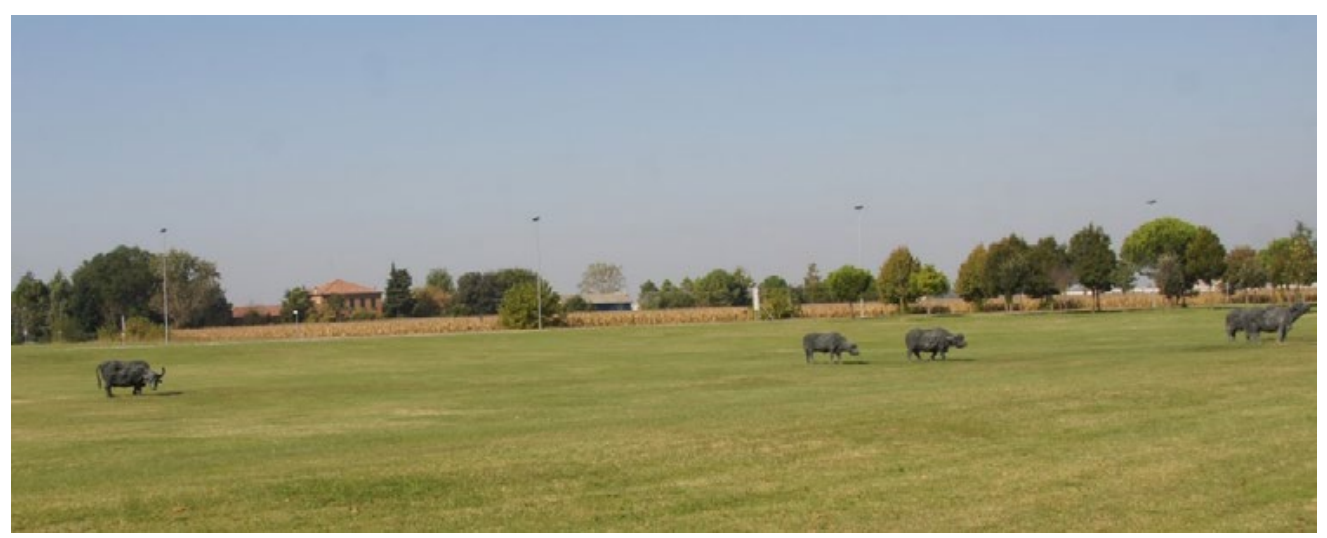

Ryc. 9. Stado bawołów naturalnej wielkości - rzeźba plenerowa w Rawennie przed bazyliką San Apollinaire in Classe, pomaga rozładować napięcie oczekujących na zwiedzanie wycieczek. Fot. N. Przesmycka

Fig. 9. A herd of life-sized buffalos - an outdoor installation in Ravenna in the front of the Basilica of San Apollinaire in Classe, helps the groups of people waiting for sightseeing tours to relieve the tension. Fig. N. Przesmycka

\section{TYMCZASOWE PRZESTRZENIE LETNIE LUB ZIMOWE}

Mieszkańcy dużych miast w krajach rozwiniętych coraz częściej chcą spędzać wolny czas w miastach, stąd widoczne w ostatnich latach dążenie do poprawy jakości przestrzeni i rozszerzenia oferty możliwości spędzania w niej czasu. Wiele miast w okresie letnim organizuje plaże dla mieszkańców. Miastem, które zapoczątkowało ten trend był Paryż, gdzie od 2002 roku bulwar na prawym brzegu Sekwany, pomiędzy Pont Neuf i Pont Sully zamieniono w publiczną plażę wysypaną piaskiem, z leżakami i parasolami. Wkrótce do wyposażenia dołączyły palmy w donicach, dopełniając wrażenia wakacyjnego kurortu. W ślady Paryża poszły inne miasta europejskie: Wiedeń (kanał Dunajski Strandbar Herrmann), Berlin, Hamburg (nad Łąbą), Warszawa, Wrocław. Obecnie miejskie „plaże” organizowane są nawet dla poszczególnych dzielnic (np. w Berlinie, Kopenhadze) i trudno znaleźć większe miasto, które nie oferowałoby mieszkańcom takiego rodzaju tymczasowej przestrzeni.

Okresowo funkcjonujące przestrzenie publiczne mogą stać atrakcją nawet w czasie, gdy warunki atmosferyczne nie pozwalają na ich funkcjonowanie. Otwarty basen zorganizowany na kanale w Kopenhadze (Islands Brygge Havenbad) jest przykładem pokazującym, ze nawet w kraju o północnym klimacie dobrze urządzona przestrzeń publiczna może funkcjonować pozwalając czerpać możliwie dużo przyjemności z każdej pory roku. Basen zrealizowano w 2003 roku zgodnie z projektem biura PLOT Architects w miejscu istniejącego wcześniej basenu tymczasowego. Jego dobre funkcjonowanie skłoniło władze miasta do zainwestowania w trwałą budowlę. Przestrzeń wpisuje się w Copenhagen's Blue Plan - element polityki miejskiej mającej na celu promocję projektów realizowanych w pobliżu nadbrzeża. ${ }^{21}$ Kompleks

21 W ramach tego ambitnego projektu ma powstać szereg sztucznych wysp, na których stworzone zostaną różnorodne atrakcje np. wyspa ptaków. Stworzona przestrzeń ma mieć charakter eksperymentalny, nowoczesny i innowacyjny. Atrakcjami mają być podwodne lekcje czy spacery po wodzie w szklanych kulach. Dodatkowo realizuje się renaturalizację fragmentów nadbrzeża poprzez wprowadzanie stopni, schodów czy kamiennych umocnień. Atrakcyjność przestrzeni mają podnieść nowe kładki rowerowe i piesze, dzięki którym przemieszczanie się w obrębie portu będzie miało charakter cyrkulacyjny. za: http://www.dezeen.com/2013/01/03/blue-plan-for-copenhagen-harbour-by-tredje-natur/. Miejskie plaże w Kopenhadze tworzone są również jako bardziej kameralne dla poszczególnych dzielnic: przy dawnej fabryce piwa Carlsberg, a w dzielnicy Christiania działa plaża Halvande. Od 2010 uchodząca za alternatywną dzielnica Østerbro ma swoją własną plażę, Svanemøllestranden. 
trzech basenów przylega do nabrzeża, które wcześniej zrewitalizowano, tworząc park sąsiadujący z dzielnicą mieszkaniową. Drewniana nawierzchnia łączy się z rekreacyjną przestrzenią trawników w parku. Dwa mniejsze baseny przeznaczone są dla dzieci, a duży basen wypełniony jest wodą z kanału, której jakość jest codziennie monitorowana. Charakterystyczna wieża do skoków $\mathrm{z}$ wody jest elegancką dominantą wysokościową założenia, a jedynym elementem kolorowym jest biało czerwona wieża ratownicza. $\mathrm{W}$ obrębie omawianej przestrzeni ma miejsce wiele aktywności pozwalających jej funkcjonować całorocznie. Jest to przestrzeń codziennej rekreacji, spacerów i komunikacji pieszej i rowerowej, a każdego tygodnia pod pergolą zbudowaną z konstrukcji dawnych suwnic odbywają się pchle targi.

Ciekawym przykładem tymczasowej ,,plaży miejskiej” połączonej z basenem jest kompleks obiektów i aranżacji przestrzeni organizowany corocznie w Wiedniu, nad kanałem Alte Dunau. Przestrzeń podzielona jest na dedykowane różnym użytkownikom (rodziny, single, wędkarze itd.) części. Na przycumowanych barkach znajdują się nie tylko letnie kawiarnie ale niektóre $\mathrm{z}$ nich przekształcane są w baseny kąpielowe.

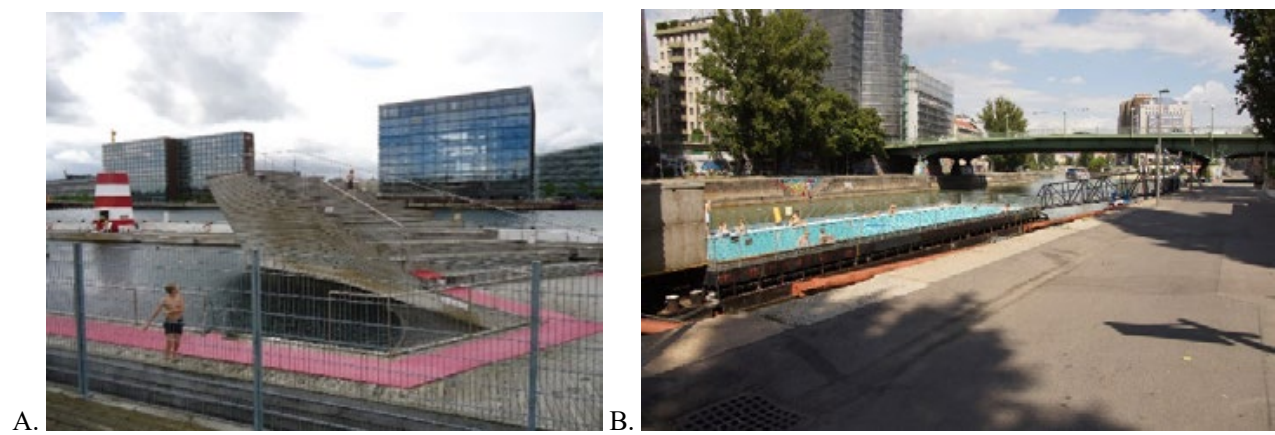

Ryc. 10. A - Kopenhaga, Islands Brygge Havenbad. Pomimo sezonowego zamknięcia, jest użytkowana, B plaża miejska z kąpieliskiem zorganizowana na barce na kanale Dunaju w Wiedniu. Fot. N. Przesmycka

Fig. 10. A - Copenhagen, Islands Brygge Havenbad is in use despite seasonable closing, B - city beach and swimming pool on the barge, Alte Dunau in Vienna. Photo N. Przesmycka

\section{PRZESTRZEŃ ZABAWY}

Zabawa, która w czasie modernizmu została sprowadzona do wydzielonych i dobrze wyposażonych placów zabaw, w ostatnich kilkunastu latach stała się oczekiwaną aktywnością w przestrzeni publicznej. Co ciekawe przestrzenie i urządzenia adresowane są nie tylko do najmłodszych użytkowników przestrzeni ale dla całkiem dorosłych. U podstaw wielu ludzkich działań leży zabawa i gra, które poprzez wprowadzenie współzawodnictwa przyczyniają się do nauki i rozwoju. W podobny sposób działają również gry i zabawy ruchów. Zabawa jest domeną nie tylko najmłodszych. Homo ludens, czyli człowiek bawiący się wykształcił się w drodze rozwoju naszej kultury, choć zabawa obecna jest również w świecie zwierząt. Małą architekturę i zagospodarowanie przestrzeni publicznych traktuje się często jako element sprzyjający integracji społecznej, a jedną $\mathrm{z}$ aktywności do tego prowadzących jest ruch i zabaw. Pojawiają się rozwiązania, w których do funkcjonowania mebla konieczna jes t interakcja $\mathrm{z}$ innymi ludźmi (słynne gigantyczne ławki w Berlinie), podobnie działają niektóre miejskie meble wielofunkcyjne, chociażby przywołane już Enzi. Ana Kuçan proponuje nawet zamiast używania określenia playground, które wiąże się z wydzielonym, schematycznym, bezpiecznym 
i zorganizowanym placem zabaw, w kontekście innowacyjnego podejścia do funkcjonalnego zagospodarowania przestrzeni publicznych, zastąpienia go pojęciem playscape 22 .

W 2010 roku w mieście Mafikeng w RPA powstała gigantyczna konstrukcja trzech huśtawek, wykonana ze zużytych opon i drewna, przymocowanych do konstrukcji stadionu Mmabatho (projekt REFUNC Jan Körbes $i$ Thjeu Donders). Aby wprawić zwisająca z wysokości 12 metrów huśtawkę w ruch potrzeba współpracy kilkunastu osób. ${ }^{23}$ Ciekawym przedsięwzięciem, zapoczątkowanym również w Południowej Afryce, łączącym elementy rewitalizacji na wielu poziomach był interdyscyplinarny projekt Roundabout Outdoor Playpump rozpoczęty w 1997 roku. ${ }^{24} \mathrm{~W}$ dotkniętych problemem niedoboru wody miejscowościach zainstalowano zero-energetyczne pompy. Napędzane siłą bawiących się na karuzelach dzieci, pompy czerpią wodę z głębinowych studni przekazując ją do zbiorników. Zbiorniki wyniesione na wysokość $6 \mathrm{~m}$ pełnią dodatkowo funkcję nośników reklam, co jest ważnym elementem z punktu widzenia lokalnej gospodarki. Pompy z placami zabaw stały się ważnym, często jedyny elementem wokół którego tworzy się przestrzeń społeczna i publiczna. Projekt ten pokazał jak w kreatywny sposób, przy minimalnym angażowaniu środków finansowych można dzięki innowacyjności zrobić coś dla trzeciego świata. Jednak po kilku latach funkcjonowania zaczął być krytykowany, za zbytnią medialność i stosunkowo niską efektywność (w stosunku do tradycyjnych pomp) oraz...oparcie na pracy dzieci. Mimo wsparcia finansowego Banku Światowego i planów uruchomienia do 2010 roku pomp zaopatrujących w ten sposób 10 milionów ludzi w wodę pitną, wobec stosunkowo niskiej efektywności pomp, od 2009 roku nie wykonuje się nowych Playpumps. ${ }^{25}$ Podobna idea przyświeca jednak organizacji generujących energię elektryczną placów zabaw ${ }^{26}$.

Popularne w krajach wysoko rozwiniętych rozwiązania niejako wymuszające współpracę $\mathrm{i}$ integrację społeczną w przestrzeniach publicznych jednak mają zupełnie inny cel. Jest to zapobieganie wykluczeniu społecznemu i zwrócenie uwagi na drugiego człowieka. W 2010 roku w Utrechcie powstały eksperymentalne mobilne meble uliczne, w formie hydraulicznie wynoszonych z posadzki platform, które w zależności od potrzeby mogły być ławkami lub stolikami. Turkusowe metalowe prostokątne płyty na co dzień wtopione są w nawierzchnię chodnika. Kiedy mieszkańcy chcą ich użyć jako ławek muszą je wyciągnąć używając do tego celu specjalnej wajchy i współpracując ze sobą.

Tymczasowe place zabaw wykorzystujące nietypowe, czasem ponad zwyczajnej wielkości elementy stają się popularnym rozwiązaniem tymczasowym, w którego projektowanie angażują się artyści i projektanci. W 2012 roku na Bulwarze Nadmorskim w powstała Akcja „Playground”, której celem było zatrzymanie ludzi w przestrzeni dotychczas „przejściowej”. W ramach niej powstały instalacje będące przeskalowanymi zabawkami: bujanym konikiem, łódką origami, gigantyczny stół z krzesłami czy „Korek Bałtycki” - pływająca po nadbrzeżu styropianowa rzeźba w kształcie gigantycznego korka od wanny ${ }^{27}$.

Mobilne, tymczasowe elementy przestrzeni publicznych mogą również sprzyjać integracji społecznej. W 2010 roku główną nagrodę w kategorii działań tymczasowych Urban Intervention Award zdobyła mobilna miejska kuchnia zaprojektowana przez architektów Daniela

22 A. Kuĉan, Playscape-in defence of public space, w: On Site. Landscape Architecture Europe, LAE Fundation, Bassel. Boston Berlin, 2009, p. 133-135

23 R. Klanten, S. Ehman, M. Hübner, L. Feireiss (ed.), 2012, Going Public. Public Architecture, Urbanism and Interventions, Gestalten, Berlin, s. 153.

24 C. Cumberlidge, L. Musgrave, 2007, Design and Landscape for People. New Approaches to renewal, Thames\&Hudson, s. 34-40.

25 https://en.wikipedia.org/wiki/Roundabout_PlayPump

$26 \mathrm{http} / /$ www.empowerplaygrounds.org/

27 D. Falkowska, 2012, Zabawa na bulwarze, „Architektura i Biznes”, 9/2012, s. 35 
Unterberga i Isabell Weiland. Skonstruowana na bazie przyczepy do roweru konstrukcja zawierała kompletne wyposażenie kuchni oraz długi stół. W miejscach, w których się pojawiała mieszkańcy spotykali się wspólnie gotując, wymieniając przepisami, jedząc i rozmawiając.

\section{TYMCZASOWAARCHITEKTURA-ELEMENTKREUJĄCYPRZESTRZEŃPUBLICZNĄ}

Przestrzenie publiczne miast chętnie wzbogacane są elementami tymczasowej architektury. Szczególnym rodzajem jej są pawilony, o funkcjach dostosowywanych do bieżących potrzeb. Często budynki te są wynikiem międzynarodowych konkursów architektonicznych, a ekspozycja wygranych struktur, często autorstwa „gwiazd architektury” przyciąga do miast miłośników architektury. Efekt ten wykorzystują przede wszystkim duże miasta.

Od 2000 roku The Serpentine Gallery (w londyńskich Kensington Gardens), zamawia pawilon ogrodowy autorstwa uznanego architekta ${ }^{28}$. Tymczasowe struktury mają rzeźbiarską formę i pełnią funkcję letniej kawiarni i pawilonu ekspozycyjnego. Forma pawilonu ogrodowego jest ekspozycją samą w sobie, przyciągając do galerii rocznie dodatkowo 200.000 zwiedzających w przeciągu pierwszych sześciu tygodni otwarcia ${ }^{29}$. Funkcja kawiarni pozwala na bezpośredni, nieformalny kontakt z architekturą. Pawilony często mają za zadanie zwrócić uwagę szeroko pojętej publiczności na jakiś problem, być jego rozwiązaniem. Prototyp samowystarczalnego energetycznie domu - FLAB House w Barcelonie, (2010 rok) funkcjonował jako atrakcja dla mieszkańców i turystów.

Kreowanie tymczasowych przestrzeni publicznych staje się często płaszczyzną do współpracy miast z uczelniami wyższymi. Tworzenie tymczasowych pawilonów jest domeną nie tylko studentów kierunków architektonicznych, ale również efektem interdyscyplinarnej współpracy. Możliwość ekspozycji własnej realizacji w środowisku miejskim, jest bardzo ważna dla przyszłych projektantów. Droga powstawania pawilonów może być różna: warsztaty, konkursy, szkoły letnie, wydarzenia kulturalne. Wiele miast widząc potencjał we współpracy z uczelniami, tworzy ramy dla działań tymczasowych w przestrzeni publicznej, poprzez zapewnienie miejsca do ekspozycji budowli lub stworzenie stałych, cyklicznych wydarzeń.

Przykładem stałej kooperacji może być Stuttgart, gdzie w ramach prac badawczych ICD Institute for Computational Design (Wydzial Architektury i Projektowania Urbanistycznego) i ITKE Institute of Building Structures and Structural Design powstają tymczasowe konstrukcje letnich pawilonów inspirowanych bionicznymi formami. Od $2010 \mathrm{roku}$ $\mathrm{w}$ przestrzeni powstawały kolejne tymczasowe pawilony zbudowane $\mathrm{z}$ drewnianych sklejkowych paneli $(2010,2011)$ lub włókien węglowych (od 2013 roku) zaprojektowanych i wykonanych przy użyciu technologii cyfrowych. Prezentowany w 2014/2015 roku pawilon powstał w wyniku inspiracji konstrukcją sieci podwodnego pająka ${ }^{30}$.

28 W 2000 roku Zaha Hadid, 2001 Daniel Libeskind, 2002 Toyo Ito, 2003 Osacar Niemeyer, 2005 Alvaro Siza i Eduardo Souto de Moura. Projekt nie jest finansowany z pieniędzy publicznych, co pozwala galerii w pełni kontrolować zamówienia.

29 S. Gaventa, 2006, New Public Spaces, London, s. 169.

30 The Institute for Computational Design (ICD) and the Institute of Building Structures and Structural Design (ITKE) prowadzą serię realizacji pawilonów badawczych. Są to prototypy budynków, na których wypróbowyuje się możliwości projektowania wspomaganego programami komputerowymi, oraz procesu symulacji i prefabrykacji w architekturze. Pawilon 2014/2015 powstał jako wynik współpracy dydaktycznej i badawczej interdyscyplinarnego i międzynarodowego programu studiów magisterskich (ITECH MSc program). Pracowali nad nim badacze i studenci architektury, konstrukcji budowlanych i nauk przyrodniczych. za: http://icd.uni-stuttgart. $\mathrm{de} / \mathrm{p}=12965$. 

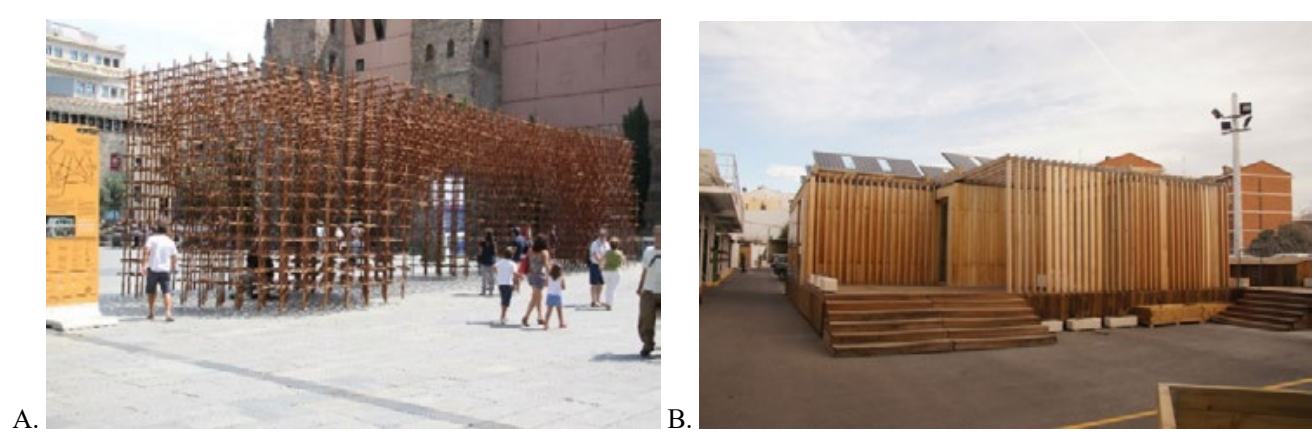

Ryc. 10. Przykłady pawilonów będących efektem warsztatów i konkursów studenckich. A - Barcelona, w trakcie ekspozycji w przestrzeni publicznej, B - Walencja, zero energetyczny pawilon- dom, po wystawieniu w przestrzeni publicznej wrócił na uczelnię. A - Fot. K. Boguszewska, B - Fot. N. Przesmycka Fig. 10. The examples of pavilions being the result of student workshops and competitions. ABarcelona, during the public space exposition, $\mathrm{B}$ - Valentia, zero-energy pavilion after being public exposed was returned to the university. A - Photo K. Boguszewska, B - Photo N. Przesmycka

\section{ZIELEŃ W TWORZENIU TYMCZASOWYCH PRZESTRZENI}

Wprowadzenie zieleni jest bardzo ważne w działaniach rewitalizacyjnych i w kreowaniu przyjaznej użytkownikowi przestrzeni publicznej. Tymczasowa zieleń ozdobna, na przykład $\mathrm{w}$ formie donic $\mathrm{z}$ kwiatami, towarzyszy od dawna przestrzeniom publicznym nadając im uroczystego, reprezentacyjnego charakteru. Jednak dopiero od kilkunastu lat zieleń istniejąca tymczasowo pełni inną rolę - ma „przywrócić” miasto ludziom. Ważnym nurtem takiego podejścia do kreowania przestrzeni publicznych jest ruch społeczny nazywany „partyzantką urbanistyczna”. Stopniowe zazielenianie miast ma różne przyczyny, oczekiwane cele i formy. W dużych miastach krajów wysokorozwiniętych zwraca się uwagę na pozytywny aspekt wprowadzania zieleni tymczasowej w kreowaniu bioróżnorodności, integracji społecznej, a nawet jako sposób na rozwiązanie kwestii głodu. ${ }^{31}$

$\mathrm{W}$ wielu miastach powstają nieformalne warzywne ogrody miejskie. Są one odpowiedzią na kilka społecznych problemów: niewiadomej jakości i pochodzenia produkty dostępne w sprzedaży, oszczędności pieniędzy i zasobów środowiska. Niektóre z nich powstały na bazie wcześniejszych akcji artystycznych (np The Union Street Urban Orchard, London), nielegalne lub zalegalizowane. Urban gardening i urabn farming są ruchami zdobywającym coraz większą popularność. Innowacyjność w tym zakresie polega na znajdowaniu nowych miejsc, w których można uprawiać rośliny i optymalnych sposobów do ich uprawy. Uprawę roślin prowadzi się w oknach, donicach czy w wyniesionych, tymczasowych rabatach. Czynnik społeczny ma tu duże znaczenie. Pojawia się własność wspólna, którą trzeba szanować i dbać. Ogródki działkowe są dobrem z którego płyną korzyści społeczne. Wykorzystanie powierzchni wertykalnych nie tylko do celów uprawiania zieleni ozdobnej ale i użytkowej.

Przykładem tymczasowego, eksperymentalnego wprowadzenia zieleni w zupełnie nowej formie do przestrzeni publicznej miasta jest Living Pavilion (proj. Ann Ha and Behrang Behin), który powstał w Nowym Yorku na Governors Island, jako efekt konkursu „City of Drems”. Obiekt zaprojektowany został zgodnie z filozofią low-tech i low-impact. Do konstrukcji wykorzystano plastikowe skrzynki po mleku (element charakterystyczny dla miasta), umieszczone

31 Urban Agriculture For Sustainable Poverty Alleviation and Food Security, http://www.fao.org/fileadmin/templates/FCIT/PDF/UPA_-WBpaper-Final_October_2008.pdf 
na łukowych ramach $\mathrm{z}$ drewna klejonego, tworząc przykrycie o parabolicznym kształcie. ${ }^{32}$ W skrzynkach zasadzono trawę, która tworzy naturalne, chłodzące zadaszenie. Po okresie jej wegetacji, skrzynki wracają do obiegu i dalej służą w swoim oryginalny przeznaczeniu. Użycie codziennych przedmiotów w niecodzienny sposób miało na celu zwrócenie uwagi na problem recyklinu, powtórnego użycia i zmiany przeznaczenia. Do sadzenia roślin nie zawsze jest potrzebna wypełniona ziemią donica - czasami wystarczy przedmiot i odrobina pomysłowości. (Ryc. 11).
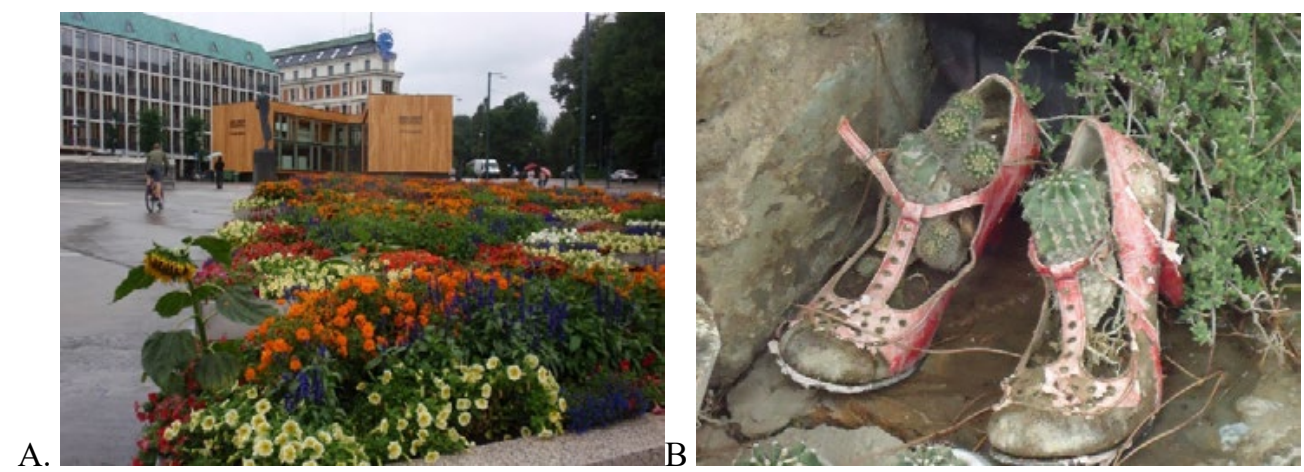

Ryc. 11. A - Niekonwencjonalne, naturalistyczne podejście do kształtowania zieleni miejskiej. Oslo. B - Niekonwencjonalna, tymczasowa donica. Izmir. Fot. N. Przesmycka

Fig. 11. A - Unconventional, naturalistic approach to shaping urban green areas. Oslo. B - unconventional, temporary flower pot. Izmir Province. Photo N. Przesmycka

\section{PODSUMOWANIE}

Obecnie granice przestrzeni publicznych są redefiniowane: tworzone są w przestrzeniach zapomnianych, na dachach budynków publicznych lub funkcjonują tymczasowo.

Dzisiejsze problemy przestrzeni publicznych będą potrzebowały innowacyjności nie tylko w zakresie rozwiązań technicznych, ale przede wszystkim dla społecznego funkcjonowania przestrzeni publicznych. Zapewnienie bezpiecznego uczestnictwa w życiu społecznym dla każdej grupy wiekowej i społecznej, poprawa bezpieczeństwa i walka z wykluczeniem są najważniejszymi wyzwaniami przed jakimi stają współczesne przestrzenie publiczne. Przytoczone przykłady pokazują że interwencje w różnej skali, czasem przy użyciu niewielkich środków finansowych mogą przynieść zamierzony efekt. 


\section{BIBLIOGRAPHY}

Aguiar Rodrigues R., A Warning to Lisbon: The Fight for Meaning in Martim Moniz, http://www.failedarchitecture. com/a-warning-to-lisbon-the-fight-for-meaning-in-martim-moniz/

Cumberlidge C., Musgrave L., 2007, Design and Landscape for People. New Approaches to renewal. Thames\&Hudson, London.

Dymna E., Rutkiewicz, M., 2012, Polskie street art, cz.2. Między anarchiq a galeria, Carta Blanca, 2012.

Falkowska D., 2012, Zabawa na bulwarze, Architektura i Biznes, 9/2012.

Frąckiewicz S., 2015, Żeby było ładnie. Rozmowy o boomie i kryzysie street artu w Polsce, Poznań, Galeria Miejska Arsenał.

Gaventa S., 2006, New Public Spaces, p. 169, London, 2006.

Gehl J., 2004, Miasto dla ludzi. p. 145, RAM, Kraków.

Klanten R., Ehman S., Hübner MFeireiss., L. (ed.), 2012, Going Public. Public Architecture, Urbanism and Interventions, Gestalten, Berlin.

Kuĉan A., 2009, Playscape-in defence of public space, [w: ]On Site. Landscape Architecture Europe, LAE Fundation Bassel. Boston Berlin.

Moor M., Rowland J., (red.), 2006, Urban Design Futures, Tylor\&Francis Group.

Rykwerth J., 2013, Pokusa miejsca. Przeszłość i przyszłość miast. Międzynarodowe Centrum Kultury, Kraków, s. 25

Urban Pioneers, Berlin: stadtenentwicklung durch Zwischennutzung, Senatverwaltung fur Stadtenwicklung Berlin und Jovis Verlag GmbH, Berlin 2007

Van Uffelen Ch., 2010, Street Furniture, Braun

http://byhaven2200.dk/

http://culture.pl/pl/tw (11/08/2015)\

http://icd.uni-stuttgart.de/?p=12965 (06/08/2015)

http://refunc.nl/?p=1171 (06/08/2015)

http://studioweave.com/

http://www.dac.dk/en/dac-life/copenhagen-X-gallery/cases/temporary-urban-spaces-at-carlsberg/

http://www.dezeen.com/2013/01/03/blue-plan-for-copenhagen-harbour-by-tredje-natur/ (07/08/2015)

http://www.empowerplaygrounds.org/ (06/08/2015)

http://www.fao.org/fileadmin/templates/FCIT/PDF/UPA_-WBpaper-Final_October_2008.pdf

http://www.targowek.info/2012/07/pomnik-palety-robi-sie-wiekszy/

http://wydzialsztuki.up.krakow.pl/?page_id=2809 (07/08/2015)

https://en.wikipedia.org/wiki/Roundabout_PlayPump (07/08/2015)

\section{METHODS OF CREATING TEMPORARY PUBLIC SPACES}

Summary. The use and creation of temporary public spaces becomes more and more popular, particularly occurring in large cities. This phenomenon remains somehow outside of the mainstream research interested in urban planning, however, it is one of the basic elements of modern urban policy. Temporary public realm can have various sources: lack of financial resources for development, a willingness to examine whether a type of function in a specific localization will work. Many public authorities today lack the financial means to resolve problems of public space. The social activities, not always lawful, resulting from the ongoing needs of the occupants or users, have very important impact on public space. Some temporary use projects show that many of them will become a professional business or may become a permanent function in the area. This paper presents some examples of temporary use or temporary creation of public spaces in chosen European cities.

Key words: temporary public spaces, urban reuse, urban art. 